\title{
Dwelling in the Apocalypse: Capitalist Modernity, Antimodernism, Zombies
}

Hrooje Tutek

Journal of French and Francophone Philosophy - Revue de la philosophie française et de langue française, Vol XXV, No 1 (2017) 27-48.

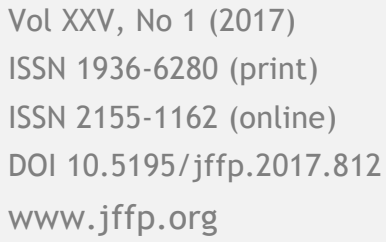

\section{(oc) EY-NO-ND}

This work is licensed under a Creative Commons Attribution-Noncommercial-No Derivative Works 3.0 United States License.

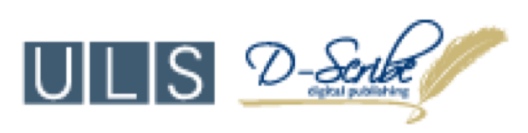

This journal is operated by the University Library System of the University of Pittsburgh as part of its D-Scribe Digital Publishing Program, and is co-sponsored by the University of Pittsburgh Press 


\title{
Dwelling in the Apocalypse
}

\section{Capitalist Modernity, Antimodernism, Zombies}

\author{
Hrvoje Tutek \\ University of Zagreb
}

The Heideggerian question posed here as "what does it mean to dwell in a global age" leaves open, invites even, the possibility of committing two conceptual mistakes from which, depending on the theoretical universe we inhabit, two separate sets of problems arise.

On the one hand, if the adverbial "in a global age" is taken to denote a radical historical caesura between "our age" and the age in which the concept was first deployed, one has to prove that the caesura is indeed not only historically operative but legitimate on an ontological level. This would, however, be a futile attempt: there hardly exists an essential, qualitative difference between the ontological regime of "our global age" and the one sketched in Heidegger's 1954 essay "Building Dwelling Thinking." We have not been blessed by any epochal turns, despite important switches - to move for a second to a different register-in regimes of accumulation. Thus, it may be concluded, the ontological question about the state of "dwelling in a precarious age" has already been posed and answered by Heidegger himself-from an ontological perspective, he is our contemporary. And of course, to such question there can in fact be only one answer: it is the same "metaphysics" that has precluded the possibility of "dwelling" (initiated a "denial of dwelling" as it is put here) throughout modernity that gave rise to our age as global. But then to avoid the mistake sketched out above and the repetition of an already accomplished analysis, the question as it is posed for us here ("what does it mean to dwell in a global age") should be taken as a politicization of the original concept, foreign to a puritanically ontological Heideggerian diagnostics, although building on its foundations: what is to be done historically at this moment to enter "dwelling"?

On the other hand, and from a materialistically-minded perspective outside of the Heideggerian conceptual universe, if the above problem of correctly posing the question of dwelling is disregarded and the adverbial

Journal of French and Francophone Philosophy | Revue de la philosophie française et de langue française 
"in a global age" taken to be less of a conceptual modification, and more of a tactical intervention, an invitation to reactivate a certain modernist criticism of modernity by relocating it to a different, postmodern, historical context, we commit the error of actually dehistoricizing the concept. The addition of historical coordinates ("global age") to Heidegger's ontological concept allows us to stretch it beyond the original horizon of its deployment while assuming that this is indeed possible, and without asking if it is desirable. Thus we escape the problematization of its own, necessarily historical charge and function for Heidegger's own location in history. This amounts to a silent vindication of a broad philosophical criticism of modernity that reverberates with deictics such as "we" and "age," and admits a set of concepts and theoretical orientation points tied to what was once identified by Theodor Adorno as "the jargon of authenticity" into what should be, it was concluded above, a politicization. If we agree that in the sphere of theory this means forging concepts that can be historically operative beyond the academic field, then such a deictic strategy is not the most efficient one and as such amounts to no more than a cry in the academic wilderness, a painful enjoyment in the pathos of speculation.

Thus the only available option for a firmly re-historicizing method of addressing the problem of dwelling (if we admit it is a real problem) is as always, to do just that: to attempt a conceptually convincing historization of this problem (and concept) at the point of its emergence in order to reveal how it bends discourse about perceived socio-historical reality into a specific ideological arrangement. If it is operative at another point in history, to situate it within a transformed historical context and see how it does the same at a different location. From this, such arrangements can be rejected, or retained, or-hopefully_an alternative arrangement can take shape.

The concept of dwelling, central for Heidegger's later philosophy and serving as a key critical tool for a diagnostic of modernity's plight, functions-perhaps we can say notoriously-on several coexisting levels. It is simultaneously an ontological category and a socio-historical prescription; a transhistorical essential, and a seemingly radical sublation of a "really existing" historical logic. In his exegesis of Heidegger's later philosophy, Julian Young confirms this by elaborating how the concept functions in two capacities - the "essential" and the "existential" one:

Dwelling is our essence, 'essential' dwelling, as we may call it, something we all possess. In modernity, however, we fail to understand our essential dwelling, fail to 'experience and take [it] over'. Encaged by metaphysics we fail to experience either our ultimate security or our mission of guardianship. That is why, though 'essentially' dwelling, modem humanity in another sense - let us call it the 'existential' sense - fails to dwell.

Journal of French and Francophone Philosophy I Revue de la philosophie française et de langue française Vol XXV, No 1 (2017) | http://www.jffp.org | DOI 10.5195/jffp.2017.812 
In other words, the concept not only enfolds a historical dimension but also projects an undeniably political one. Putting aside the usual proposition that Heidegger's thought is "non-political," ${ }_{3}$ I would like to reconstruct here the basic contours of a political "suggestivity" emerging from the method of his later philosophy. Its formula is the following: dwelling as "man's" essence is inescapable, it is man's destiny. But man somehow falls short of it, does not "bring dwelling to the fullness of its nature". This occurs by not perceiving "the real plight of dwelling as the plight," and by not "[giving] thought to [man's] homelessness." ${ }_{4}$ Hence modern man does not only fail, but fails tragically, insofar as "he" fails to retrieve what already belongs to him. A certain politics of dwelling unavoidably emerges out of this: firstly, from the diagnosis of failure, suggesting on the one hand negatively that man is "doing it wrong", but implying on the other positively that there is a correct way of doing it. Secondly, from the gesture of retrieval ("pick up what's yours") that is suggested as the minimal praxis of this politics. Heidegger's carefully crafted vocabulary famously indicates an essentially conservationist purpose for the gesture of retrieval: "staying with," "preserving," "safeguarding," "bringing into fullness," "leaving in its own nature":

Real sparing is something positive and takes place when we leave something beforehand in its own nature, when we return it specifically to its being, when we 'free' it in the real sense of the word into a preserve of peace. To dwell, to be set at peace, means to remain at peace within the free, the preserve, the free sphere that safeguards each thing in its nature. The fundamental character of dwelling is this sparing and preserving. ${ }^{5}$

The content of the retrieval is ontological. A successful retrieval is a revelation of being, and, speaking from the "ontic," politicized, perspective of man who failed, its restoration. Which brings us to Fred Dallmayr's important point that being "for Heidegger was essentially a synonym for freedom." ${ }^{\circ}$ So the politics of dwelling is a prophetic politics, insofar as it depends on a recognition of truth and fulfillment of its liberatory possibility as already anticipated, foretold in being. And it is a politics of restoration insofar as this truth was once (prior to metaphysics) unconcealed. And it is a politics of epiphany insofar as the recognition of truth and the fulfillment of its possibility remain one.

As a useful heuristic and in an attempt to situate this project as a historical one, it is interesting to compare this to the contemporaneous philosophy of Ernst Bloch that, despite fundamental differences, encompasses important related themes. A similar notion of freedom by retrieval can be discerned in the famous conclusion to Bloch's The Principle of Hope: "Once he has grasped himself and established what is his, without expropriation and alienation, in real democracy, there arises in the world something which shines into the childhood of all and in which no one has

Journal of French and Francophone Philosophy | Revue de la philosophie française et de langue française Vol XXV, No 1 (2017) | http://www.jffp.org | DOI 10.5195/jffp.2017.812 
yet been: homeland." ${ }^{\prime}$ Despite the explicitly programmatic thrust of concepts such as "real democracy" and "expropriation," suggesting Bloch's more "sociological" preoccupations, both philosophies tie the concept of freedom closely to the problem of habitation: "dwelling" and "homeland," reflecting concerns of belonging and recognition, stand opposed to the homelessness and alienation of the modern man. Both perceive the epochal split between "man" and "being," and propose a re-creation of a holistic historical domain in which this split would be sutured. Both propositions are also based on openly paradoxical conceptions: homeland is recognized, although no one has seen it; dwelling is simultaneously to be "set at peace" [zum Frieden gebracht sein] and "to remain at peace" [eingefriedet bleiben in das Frye]. The relief of the perceived tension between man and being is imagined in the form of paradox that seems to neutralize this tension (the "ailments" of metaphysics/alienation). In a typically modernist fashion, the paradoxes mark the spot where a utopian launch into the poetic is to occur.

But again, despite these similarities, Bloch's political conception is a pragmatic and an activist one, admitting in an "ontic" logic of political cause and effect. There are obstacles to homeland's emergence (exploitation, democratic deficit...) - remove them-and man feels at home in the world, autonomously realizing the potential that has been given to him. It is a subjectivist and a humanist account, unacceptable from a Heideggerian perspective. The Principle of Hope itself is what might be called a monumental anthropological compendium, an account of human practices and cultural activity motivated by the "Utopian impulse," immanent to historical development and serving to pass on the promise of freedom until, as Bloch famously wrote, true Genesis is found not at the beginning but at the end. Anson Rabinbach elaborates that "history for Bloch is predicated on a future-oriented knowledge that transcends the empirical order of things, that does not take flight in false images or fall prey to naturalism, but is directed beyond the existing world toward a yet unrealized "messianic goal." Bloch's "man" is forward-oriented and steered towards the future Genesis by "knowledge" ingrained in a series of Utopian, prefigurative manifestations.

Against this futuristic gnosis and humanist background, later Heidegger's ontology appears rather static. As opposed to Bloch, the "promise of freedom" or the realization of the possibility of (existential) dwelling is not dependent on a causal interaction with the political. Social relations and institutional barriers are not what one should be concentrating on: "the real plight of dwelling does not lie in a lack of houses." The real plight of dwelling is "older" and consists of the need for "mortals" to "ever learn to dwell." The "homelessness," Heidegger's diagnosis of the ailments afflicting the man of modernity, is an effect of man's failure to think about this real plight, of a lack of knowledge necessary for the alleviation of homelessness' "misery." Once in possession of this knowledge, "it is a 
misery no longer." "Thus Heidegger's "cure" turns out to be a thoroughly cognitive one, dependent on the consistency of ontological thought-effort (as opposed to that, even though Bloch's has a fundamental cognitive component to it-the "future-oriented knowledge"-it has to be supplemented by pragmatic Utopian prefigurations).

Thus conceived, thoroughly severed from subjectivist interventionism, dwelling - whose "fundamental character is sparing and preserving"-is simply "to remain at peace." "It is not entered into in its fullness by way of meddling with the ontic but by way of an onto-contemplative relation to being as revealed in things, through a conservationist effort whose ultimate aim is the "safeguarding [of] each thing in its nature." Dwelling is always "a staying with things."

But dwelling, as we already mentioned, has an additional dimension: It is simultaneously "to remain at peace" but also to be "set at peace" within "the free sphere that safeguards each thing in its nature." It is to be freed by remaining undisturbed. The category functions simultaneously as a condition of possibility of the escape from modernity's plight and its successful conclusion, the starting point and the final destination. If we draw this circularity at the heart of later Heidegger's criticism of modernity out onto the surface of history, we might try to determine if it has a sociopolitical equivalent. But first let us further elaborate its logic by describing this project as providing a conceptual framework meant to envision a practice of movement while remaining at the same place, or remaining at the same place while moving. Heidegger himself provides a practical example of this with his bridge in Heidelberg:

From this spot right here, we are there at the bridge - we are by no means at some representational content in our consciousness. From right here we may even be much nearer to that bridge and to what it makes room for than someone who uses it daily as an indifferent river crossing.... I am never here only, as this encapsulated body; rather, I am there, that is, I already pervade the room, and only thus can I go through it. ${ }^{13}$

What connects two states, locations, things usually registered as separate, what equates them is belonging to the same, immanently positive order ("real sparing is something positive"14).

Insofar as it is necessary to engage in thought ("thinking for the sake of dwelling") in order to facilitate the revelation of that order, and insofar as the revelation (and its safeguarding) offers an opportunity for safety beyond the failures of metaphysics and modernity, it is necessary to conceptualize that order as possessing a positive transformative latency which is activated upon its disclosure. The historical content of what appears as this latency is irrelevant, what is important is following the necessary, ontologically legitimate procedures for its unconcealment and preservation in dwelling

Journal of French and Francophone Philosophy | Revue de la philosophie française et de langue française Vol XXV, No 1 (2017) | http://www.jffp.org | DOI 10.5195/jffp.2017.812 
(from this perspective, Heidegger surprisingly appears as almost a formalist $\left.{ }^{15}\right)$.

And if to dwell is to "inhabit 'the poetic'," "16 we should also assume that "mortals" recognize the true revelation of being as the poetic effect, as a mystical (not in the liberal meaning of "irrational") experience of being in its immediacy. Thus also the criteria for activity legitimate for true dwellers are shifted from the terrain of "will" (science, politics, etc.) to the terrain of affect.

This is perhaps the moment where a space opens up for the introduction of a more pragmatic criticism hinted at above. If we theorize the "really existing" modernist reactionary political movements, i.e. fascism, as preservationist, as a grand historical flurry of activity aimed at preserving the stability of the (capitalist) order behind it (this is an extension of Walter Benjamin's dictum that behind every fascism there is a failed revolution), and if we add that for this they required a poetization of the political, a politics of affective intoxication, we can easily establish that there is a strong analogy between the logic of the conservationist political "suggestivity" of dwelling and the conservatism of really existing reactionary modernist political movements.

From this reconstruction of the minimal politics of dwelling, understood among other things as a critique of modernity, I would like to move on to an examination of whether and in what forms do such conceptions survive culturally in the "global age." I would like to propose that there is a prominent contemporary cultural form in which the sorts of concerns characteristic for a broader modernist critique of modernity are rearticulated and redeployed ideologically to form a characteristic cultural imaginary of the "West" as it exists in the epoch of capitalist universality.

It seems that today the narrative genre whose central concern is the questioning of the existential possibilities of dwelling is precisely the one that enacts scenarios of its ultimate obstruction. By this I mean, of course, the tediously omnipresent narratives of the apocalypse. In its various incarnations, the apocalyptic genre has been famously prominent during the Cold War period, so much so that the "increasing familiarity and plausibility of the idea of an imminent apocalypse has promoted the production of surreal apocalyptic visions both inside and outside the genre." ${ }_{18}$ During the past quarter century this prominence has been maintained, if perhaps in guises different from the nuclear holocaust, the apocalyptic dominant of the Cold War. Instead we find natural disasters, alien invasions, global failures of technology, and most importantly: zombies. The horizon of historical possibility at the "End of History" seems to be a narrowly eschatological one. This, however, might be a misleading claim to make. As Frank Kermode's famous study examining apocalyptic imagination across centuries demonstrates, "there is nothing distinguishing about 
eschatological anxiety." ${ }_{19}$ In other words, a panoramic historical overview reveals a persistent apocalyptic tradition seemingly justifying the conclusion that apocalyptic narrative is as transhistorical a phenomenon as only a broadly conceived literary "mode," such as the comic or the tragic, could be. But though it might be true that, with a loose enough definition and periodization, there is no "epoch" this side of Utopia without processing of "eschatological anxiety" through one cultural form or another, this approach simply confirms the presence of the "mode," but fails to account for its motivation, prominence, and function, telling us nothing distinguishing of the discursive frames and genericity of an epoch, and thus nothing of the epoch itself. ${ }^{20}$ Hence an adjusted, more sensitive approach would attempt to reveal that there is, indeed, something distinguishing about contemporary eschatological anxiety. In fact, it could be claimed that it is precisely the contemporary inflection of the "mode" that should be regarded as one of the central spaces for the imaginary enactment of the "epochal" questions of the "End of History," or capitalist universality, however we might choose to periodize it. Ontological inquiry being immanent to the narrative logic of the form, apocalyptic narrative is uniquely suited to this in an age that smugly treats its present as the fulfillment of its eschatology.

One should account for such treatment on an ideological level. Our secularized apocalypse has been transformed from a faraway promise of teleological conclusion, a dream of rapture, to a simple cautionary tale, a moralist warning of modernity's hubris. But since in every moralist there is also a pervert, so is the cultural enjoyment of apocalyptic narratives not simply a sensible, didactic consideration of danger, but also an onanistic pleasure: "We can actually destroy the world. How powerful we are."

But to ensure that "we" remain as powerful, a more perfidious warning is added. The consequence of what Jameson called the "waning of historicity" has been that the violent, modernist intuition of historical possibility is dulled into a skepticism that acts as a self-fulfilling prophecy: failing to imagine historical rupture as anything but necessarily catastrophic is surely helpful in ensuring that such ruptures will be avoided. Under such conditions, where a focus on the constructive dimension of historical rupture is replaced by an obsession with the destructive one, the intuition of historical possibility is repressed but constantly returns as the apocalypse. From this vantage point the contemporary apocalypse is revealed as a degenerate Utopia. To put it differently, under the conditions of capitalist universality the absence of Utopia as a regulative ideal registers as the apocalypse.

More positively, and following from this: as a prominent cultural form, apocalyptic narrative cannot be sustained simply by a negative ideological function, it cannot functionally exist as a blunt negation of Utopia but also has to offer a Utopian charge of its own. This dialectic of apocalypse and Utopia, presumably universal, has been noted in passing by

Journal of French and Francophone Philosophy | Revue de la philosophie française et de langue française Vol XXV, No 1 (2017) | http://www.jffp.org | DOI 10.5195/jffp.2017.812 
Jacques Derrida in a lecture entitled "Of an Apocalyptic Tone Recently Adopted in Philosophy" where he writes: "we know that every apocalyptic eschatology is promised in the name of light, of seeing and vision, and a light of light, of a light brighter than all the lights it makes possible." ${ }^{21}$ What is this light in the case of our secular apocalypse?

The age of universalized capitalism-with its attendant phenomena of expansion of financialization, globalization of production, etc., that go in step with technological changes of the "information age"-is in "postideological" Western techno-plutocracies characterized by a general and often aestheticized $^{22}$ sense of overcomplexity, as well as a very real experience of political impotence and disenfranchisement. ${ }^{23}$ The historical development of capitalism led to a need for new institutional frameworks for accumulation and consequent establishment of suprastate institutions and global circulation of commodities, or in other words, to a relative homogenization of the institutional field in which various capitals compete in a common arena on a global level. But the old proletariat has meanwhile been forced to endure not simply a breakdown of its social welfare institutions, but with them more broadly a breakdown of a specific form of institutions of sociality. This has had consequences on the level of culture, one of them being the lack of what Jameson calls the "cultural dominant," leading in turn to the "view of present history as sheer heterogeneity, random difference, a coexistence of a host of distinct forces whose effectivity is undecidable." ${ }_{24}$ Jameson's own method of totalization has been a possible theoretical answer to this. But I would propose here that an analogous answer to the disorienting ideological effect of the combination of overcomplexity and exposure to "random difference" has also developed in a narrative form - as the apocalyptic narrative of capitalist universality. A more dramatic and effective totalization-an illuminating logic that everything can be related to-than the end of the world can hardly be imagined. And even though it is a spurious logic, it is borne out of a cultural necessity to think, let us allow a philosophical indulgence, the wholeness of the world.

This is also the right place to consider this by going back to the Heideggerian problematic of dwelling discussed above. The complex of practices and procedures that guide dwelling-building as letting-dwell, setting at peace, safeguarding, etc.-all serve to facilitate the disclosure of being. In Heidegger's poetically charged vocabulary, such dwelling "occurs as the fourfold preservation of the fourfold", or in other words, it is a revelation and reaffirmation of the world as a compound. ${ }^{25}$ This is also where the poetic effect of dwelling comes from, dwelling "lights up" the compound of the dweller's world. ${ }^{26}$ If we conceive of apocalyptic narrative as a preconceptual totalizing gesture, a narrative conjuring of a universal framework of reference, and in addition remember the etymology of the term apocalypse as revelation or disclosure, we can relate this to the "poetic 
lighting up" of dwelling: the illuminating effects of our apocalypse, like ontological world-disclosure, also strive to reaffirm, in its compound nature, the whole of being. So a formula of a quite specific historical-culturalpolitical imaginary arises: to inhabit the poetic, we must first pass through the apocalypse.

But access to totality is in this narrative genre very often reimagined not simply at the price of an abstract total collapse, but at the price of a wholesale abandonment of modernity. Insofar as this is true, the contemporary apocalypse is a dominantly Heideggerian genre, or at least a genre echoing a set of critical habits for which a 20th century anti-modern hostility is central. Roughly, I think these habits can be classified as firstly, recollective metod (a conception of finding a way out through a "return to," an analeptic leap), secondly reconcretization (an affirmation of practice, objects, and use value as opposed to thought, abstraction, and exchange value), and thirdly overcoming subjectivity (an escape from not only the "Cartesian hubris," but from what Renata Salecl calls "tyranny of choice," desire exploited by capital, and ultimately demands of liberal citizenship).

As these themes have historically emerged in the traditions of modernist criticism of and disenchantment with modernity only to be reactivated and redeployed within contemporary narrative genres sharing similar concerns, one might call them undead, zombie criticisms. And what better setting for their redeployment than the pinnacle of contemporary apocalyptic imaginary, the zombie apocalypse?

If Deleuze and Guattari were correct in identifying the zombie as "the only modern myth," ${ }^{27}$ it is unsurprising that its many recent interpreters have applied the modern myth-busting procedure of historical materialist allegoresis to address it (including Deleuze and Guattari, who claim elsewhere that "zombie is a work myth, not a war myth," ${ }_{28}$ i.e. its sociohistorical referent is labor). In fact, there has been an entire strain of recent historical materialist analysis more or less consciously updating Marx's original Gothic imaginary for the age of the zombie..$^{29}$ And certainly, the zombie immediately strikes one as an aptly functional figure to introduce a touch of necessary horror to the age of bailed out banks, infused with capital-dead labor-only to come back to life as the institutional undead of capitalism, plodding through a ravaged scenery of the post-crisis world. Or, depending on the context, level of abstraction, and element in the process of accumulation we want to concentrate on, to the age of immigrant labor and massive unemployment on the periphery. ${ }^{30}$ But perhaps it is theoretically best justified, as Steve Shaviro has argued, to observe the zombie, as opposed to Marx's vampire, as a more appropriate figure for capital itself in the age of capitalist universality."

In any case, this work of allegoresis has been productive and useful, and it sets the coordinates within which "totalizing" readings of the zombie

Journal of French and Francophone Philosophy | Revue de la philosophie française et de langue française Vol XXV, No 1 (2017) | http://www.jffp.org | DOI 10.5195/jffp.2017.812 
apocalypse as a genre should operate. But it seems that its most important contemporary developments steer us away from the focus on the figure of the zombie and the allegoresis that it invites to a different type of symptomatic reading. The allegorical structure of the zombie apocalypse, far from simply being reproduced through different plot variations, has recently been subsumed into an innovative effort to extend and repurpose the genre. To be able to go into that in more detail, we need to focus on the peculiar habits and rituals of the genre's reception, as well as the fact it acquired an amount of popularity and even a certain cultural prestige that only forms central to the "popular imagination" achieve. Of course, under capitalism, this also means that an entire cultural sub-industry is predicated on these habits and rituals, i.e. what might provisionally be called the will to apocalypse.

The genre had the rare honor to be codified as the ultimate postmodern fantasy by institutions of the US state. This occurred with a metafictional move by the US Centers for Disease Control and Prevention in 2011, which attempted to demonstrate popular cultural literacy and harness it for the purposes of a public safety campaign by cleverly using the zombie trope. The CDC first published a blog article entitled Preparedness 101: Zombie Apocalypse detailing the best way to prepare for the event. This generated an unprecedented amount of public interest, crashing their website, and soon after, an official, publicly funded zombie comic entitled Zombie Pandemic appeared, with further useful instructions.

On the opposite side of the key duality of our age, the market, we find the same enthusiasm. It is perhaps enough to look at the first page of Amazon search results for the term "zombie" in order to confirm how appropriate a concept "the will to apocalypse" is for the rituals of this genre's reception. These days one can find there several survival guides in book form to help prepare for the apocalypse (most notably Max Brooks' Zombie Survival Guide: Complete Protection from the Living Dead and Lauren Wilson and Kristian Bauthus's The Art of Eating through the Zombie Apocalypse: A Cookbook and Culinary Survival Guide), along with zombiehead plush slippers (you put your feet in the zombie's mouth), and perhaps most explicitly, a t-shirt with the inscription "The hardest part about a zombie apocalypse will be to act like I'm not excited."

What this zombie folklore suggests is not simply that the zombie apocalypse seems to be the preferred apocalyptic scenario of the post-Cold War era, but that instead of approaching it as a cautionary tale, one should approach it as a collective fantasy. Rituals of the genre's reception encompass enthusiasm and identification, despite the gruesome consequences of that particular fantasy's realization (of course, it would be reasonable to suggest that this might precisely be the point, but more on that shortly). The logical question to ask is why is it imagined as desirable? There must be a light promised even in the name of the zombie apocalypse. After

Journal of French and Francophone Philosophy | Revue de la philosophie française et de langue française

Vol XXV, No 1 (2017) | http://www.jffp.org | DOI 10.5195/jffp.2017.812 
all, narratives of the nuclear holocaust, ecological or cosmic disasters have not awoken the same type of excited expectation as the hordes of the undead feasting on the flesh of the living. This might be a simple question of "too close for comfort"-the Verfremdungseffekt of a fantastical scenario makes it easier to enact fantasies of social destruction and regeneration without the burden of facing the realistic possibility of it actually happening. However, neither have the similarly unlikely War of the Worlds scenarios of alien invasions and subsequent wars with the invaders ever been desired with quite the same millenarian zeal. The reason for this might be quite a practical, or more precisely, a narratological one. The other mentioned scenarios are simply not so well-adapted for the purpose of probing what it means to inhabit a world beyond the compulsions of capitalist modernity, what it means to dwell in the "beyond." A few examples: in their most conspicuous, Hollywood forms wars against aliens usually "unite humanity" and provide an opportunity for a reinvigorated, heroic beginning from exactly where we left off. Aliens are here just an outsourced enemy, and the conflict reverses the effects of overproduction and activates a new cycle of accumulation. Nuclear holocausts are proper ends of the world as they not only destroy everything but exlude the possibility of reconstruction for as long as it takes for radioctive particles to decay. And natural disasters are one-time, "short sharp shock" events whose randomness and enormity is such that they become socially meaningless. So back to the zombie fantasy. Properly entertaining it, or in more technical terms, becoming the implied reader of the genre, one fantasizes about weapons and vehicles one would use during the zombie outbreak, about practical ways of securing food, about shelter, supplies, protection of loved ones, and best ways to eliminate threats. One develops a system of one's own (every character in the apocalyptic narrative has their own survivalist identity) and imagines it is the best and the most efficient one. In other words, one imagines survival while everybody else dies. It is from this perspective, at least partially, a narcissistic dream of a Darwinist social purge.

But simultaneously, and more relevantly, such a framework "[permits] an extended thought experiment about the reconstitution of community life under conditions of severe privation and perpetual danger." ${ }^{\prime 2}$ It would be too facile to use this to draw an analogy between "severe privation and perpetual danger" of the zombie apocalypse and the one of the precarious capitalist everyday. But indeed, in a social arrangement in which, as Margaret Thatcher famously pronounced, "there is no such thing as society," complete devastation seems to be a logical prerequisite for a renewed thinking about social life. What this seems to mean at this point in history, however, at least in the core of the worldsystem, is that the will to zombie apocalypse, the cultural demand for an "extended thought experiment" materializes in the zombie anti-modernism reminiscent of the critique of modernity we analyzed at the beginning. To 
elaborate this, we can finally turn to the most interesting and successful recent example of the genre.

In the oft-quoted words of Robert Kirkman, the writer and, together with artist Tony Moore, creator of The Walking Dead, a popular comic that formed the basis of a record-breaking, award-winning AMC's TV series, the comic grew out of the need for precisely the extended experiment mentioned above, as Kirkman wanted to create "a zombie movie that never ends." The Walking Dead first appeared in 2003 and has had a publication history that very few comics accomplish. After 144 issues and 12 years, in 2015 it is still going strong. In his introduction-cum-mission statement in the comic's first issue, Kirkman writes that "good zombie movies show us how messed up we are, they make us question our station in society...and our society's station in the world.... With 'The Walking Dead' I want to explore how people deal with extreme situations and how these events CHANGE them. I'm in this for the long haul.... I hope you guys are looking forward to a sprawling epic." ${ }^{33}$

And indeed, it has been sprawling, and there has been plenty of change. Besides witnessing total social collapse as an unknown contagion turns people into flesh-eating zombies, the characters are exposed to an unrelenting barrage of traumatic experiences: from watching loved ones getting ripped apart by zombie attacks, fighting to death against competing groups of survivors over scarce resources, to various isolated instances of rape, murder, and mutilation in a narrative that now spans years. All of this under the constant shadow of what for the most part of the series published so far seemed as one of the rare certainties in the world of The Walking Dead-the impossibility to establish long-term safety and a stable postapocalyptic community.

But interestingly, it is not zombies, who after the initial shock eventually become simply another blind force of nature, an environmental condition one confronts in a similar manner as one confronts the weather, who are the main source of instability and horror. It is other humans. As the central character, former police officer Rick Grimes, realizes slightly more than half way into the published narrative: "I can't believe it took me this long to realize this. After so long, being driven from one place to the next... I noticed, it was always people - that was the problem. I can't believe I'm saying this but the dead...They're a manageable threat." ${ }^{34}$

One should also transfer this observation to the level of narrative form: it is not the zombies, a relatively exhausted allegorical trope of which George Romero remains the master, that maintain the dramatic tension of the narrative. Allegory is not a structural dominant here. (Even though Kirkman's take on it introduced an important innovation: all humans carry the contagion even if they are not bitten, effectively equating them with zombies.) Zombies provide a convenient genre code and a framework of 
narrative limitations and possibilities, a logic that makes the development of a coherent scenario possible. But The Walking Dead extends the Romeroesque "allegory of contemporary society" to the point of breaking its boundaries. The epic sprawl of the narrative provides sufficient terrain for staging series of narrative psychosocial "experiments," following through with the logic of the apocalyptic world far beyond what a standard nonserial narrative format would allow. In The Walking Dead, these experiments focus on the characters (who are regularly subjected to harrowing experiences and routinely killed-off) and their interactions in an almost sadistic determination to test and display presumed psychological breaking points and speculate about dynamics of social conflict. But despite such a focus, The Walking Dead is not an ethical treatise and steers clear of most temptations of sentimental moralism (the TV series, perhaps unsurprisingly, emphasizes this dimension much more). Despite the oftenheard cliché, the narrative is not "about making hard choices" for the simple reason that the choices it dramatizes are not hard. Certainly, they are traumatic, dangerous, and often gruesome, but rarely are they complex or paradoxical, and in most cases their consequences are easily predictable and unfold immediately. In a way, this is directly opposed to the sort of choices we are generally used to making in our pre-apocalyptic innocence (or, depending on your position, corruption). The spectrum of options available for a single choice in The Walking Dead is extremely narrow and the longest-surviving central characters quickly learn to make them in a brutally simple and straightforwardly utilitarian manner in order to protect family, avoid strangers, kill threats. The ethical universe of this apocalyptic narrative, despite its drama, is not only rather spare, but, formally speaking, pastoral. And the trauma resulting from the necessity of regularly having to make such choices might be serious, but it is eventually neutralized as the characters regularly "grow" and "change" in such a way as to internalize the horrific necessities their world mandates. The others are simply "weak." The constant discussions of guilt, conscience, and necessity between characters soon become a formalized ritual whose function is to cement what everybody already knows: "It had to be done." And since everybody already knows it has to be done, it is not really a choice. Insofar as the subject of capitalist universality is trapped by Salecl's tyranny of choice, The Walking Dead allows its subjects to escape the tyranny-and indeed, choice as such-and in effect overcome subjectivity. In a community of readers of apocalyptic narrative (as witnessed by the letters column in the comic), the horizon of expectation is such that identification with characters and fantasies of personal "survival systems" discussed above extend this effect until it becomes an intersubjective one. The implied reader also knows that it had to be done.

And to be sure, when things need to be done, we need doers who are ready to do them. As one of the comic's favorite characters, a katanawielding ex-lawyer Michonne, frames it while explaining she is certain her

Journal of French and Francophone Philosophy | Revue de la philosophie française et de langue française Vol XXV, No 1 (2017) | http://www.jffp.org | DOI 10.5195/jffp.2017.812 
children are dead because they were in the care of their father when the disaster struck: "I have no idea where they went, or if they're alive. But I know they're dead. I just know there's no way they made it. My husband, Dominic, he... He couldn't use a screwdriver. He was an artist." ${ }_{35}$ The end of the world, obviously, is no place for artists. At least not bourgeois artists, the soft, daydreaming kind. Instead, it is a place for the resolute, the practical, the ruthless, the flower of the apocalypse. One of those is the central character Rick Grimes, who is slightly surprised as he grows into his role of a natural-born post-apocalyptic leader, or his son Carl ("as strong as his father"), who finds his place in one of the stable communities, years into the apocalypse by becoming a blacksmith's apprentice ("a valuable trade," says Rick). As opposed to Michonne's dead husband, Carl loves "making useful things." ${ }_{36}$ And Michonne herself, even though everybody she loved might be dead, finds solace in the glory of un-alienated labor:

Everyone has a job and that job never stops. You work until you feel like your back is going to break and then you collapse and sleep like you've never slept before. And that's only if things are going well, which almost never happens... We had some shit go down out there. Life on the open water, it's hard. There's no time to think about what happened to you... or what you did. You just work... It's glorious. ${ }^{37}$

These and other equivalent motifs, carefully reveal the world after the end of the world not as a punishment, but as a redemption. The cult of hard work, use value as the only value-form, disappearance of abstraction (in his more artistic attempts, Carl sculpts figurines of people and animals to trade for other goods) and no general equivalent (the communities function on a strictly regulated system of barter, there is no money). Things return to being things, they are reconcretized. And mortals "stay with them," rediscovering crafts "which still [use their] tools and frames as things." ${ }_{s 8}$ The conditions for dwelling in its existential capacity are recreated at the price of an apocalypse that slowly takes on the shape of a utopia.

That something similar to this is in fact the intended point of such motifs is further emphasized by the text that appears on the back cover of The Walking Dead Compendium. The text reproduces a version of the standard popular critique of late capitalism as "consumerism" although radicalized by the introduction of the dialectical idea of salvation through collapse, and authentic living and labor. It is worth quoting in full:

How many hours are in a day when you don't spend half of them watching television? When is the last time any of us REALLY worked to get something that we wanted? How long has it been since any of us really NEEDED something that we WANTED? The world we knew is gone. The world of commerce and frivolous necessity has been replaced by a world of survival and 
responsibility. An epidemic of apocalyptic proportions has swept the globe causing the dead to rise and feed on the living. In a matter of months society has crumbled - no government, no grocery stores, no mail delivery, no cable TV. In a world ruled by the dead we are forced to finally start living. ${ }^{39}$

The same sentiment is further explored elsewhere in the narrative. After the initial period of chaos, nomadic survival, and war, a stable network of communities dependent on agriculture and crafts supplemented with foraging is established. For at least a couple of years, they last without major disturbances and the inhabitants develop a sense of belonging, safety, and stability. As Rick Grimes, who is by then not only the leader of one of the communities but the visionary founding father of the "confederation," says to another leader, Maggie Greene, as they stand on a balcony overlooking the settlement they helped build and develop: "Truth is, things are almost better than before this all started."

And even some of the antagonists feel the same, even though theirs is a radically different idea of belonging. Alpha, the leader of a herd of survivors who regress back to what they see as humanity's true, animal-like nature issues a warning to Rick and Carl, whose way of life she sees as not radical enough, as vainly accepting the false, technological mode of being that will eventually lead back to the reconstruction of the fallen world:

You've built a shrine to a long-dead world.... We are animals who always pretended we are not. You work and toil your days away...Working toward restoring a life where you exercise so you can sit in a chair and let a box lie to you until all your thoughts are gone. My people? Our lives are true. We live the full lives we were always meant to. You strive to return to a life as slaves to our petty desires...Instead of recognizing the gift this world has to offer. The gift of freedom. ${ }^{41}$

In this contest in authenticity one could perhaps detect echoes of a perverted Heideggerian ontology. Alpha refuses "productivist metaphysics," advocating a communal lifeworld bringing into fullness the essential capacities of "mortals", recognizing/accepting the transformative latency ("the gift") immanent to being, which, unsurprisingly, manifests as freedom. In comparison to Rick's future-oriented, technological community obsessed with safety, they do seem to have a point. However, they are imitators-not only of "animals" but of zombies. They wear masks and suits made of zombie skin to blend in undetected with the undead so that they can travel with and live among them for protection. They abandon the quest for a properly human ontological arrangement by imagining they have access to the one of animals. Unsurprisingly, they also refuse to build, they stay under the open skies and huddle together in the wild. They do not "stay with things." In their inauthentic radicalism, zombie imitation is the only 
guarantee of survival they have available. As it turns out, the cost of clinging to this precarious idealism is their cruelty and murderous territorialism.

As opposed to that, Rick's farming community builds. It practices crafts, barters, and develops organic communal rituals, strongly reminiscent of the US frontier myths. But with it, The Walking Dead introduces, at least for now, an interesting social innovation-anti-commercialism. Before we move on to further explain this, it might be helpful to frame this point by referring to Andrew Collier's criticism of Heidegger's analysis of technology and "productivist metaphysics." Collier argues that the "truth underlying his critique of modernity" is unrecognized by Heidegger and can be extracted by reference to the Aristotelian-Marxist distinction between use value and exchange value, or in other words "that modernity, as capitalism, is dominated by exchange-value-driven production, not use-value-driven production." ${ }^{22}$ In his critique of technology, Heidegger misses the crucial point by confusing the level of technological development with its goals. The great battle for ontological transformation is not fought between the windmill and the hydroelectric dam but, more essentially and conceptually justified, between use value and exchange value:

The real ancestors of the stockpile attitude are neither the craftworker Socrates nor the aristocrat Plato, but the sophists. It is a commercialist meta-physics not a productivist one.... [It] is not the level of technology that is essential, but its goals.... Water mills, while characteristic of the feudal mode of production, did operate for some hundreds of years in market economies; and hydroelectric power stations, while first built in capitalist societies, could exist in a use-value-driven communist society.... A use-value-driven system of planning might still lead to the building of hydroelectric power stations. But the decision process would take into account the intrinsic value of the river system, setting it against the incommensurable value of increased electricity generation and deciding between them not on the basis of any countable units of value, but of an opinion about whether the world (or that part of it) would be a better place to live in with the untransformed river and less electricity, or with the transformed river and more electricity. Only those who lived in that part of the world would be in a position to make such a decision..... ${ }^{43}$

In Collier's decisionist account, which would most likely be dismissed as "subjectivist" by a Heideggerian counter-argument, there is no essence of the hydroelectric dam outside history. We can dwell, and still have a world that is lit up-electrically. At first glance, it seems that there is a trace of that realization and of the awareness of the essential difference between commodity production and use-value production in Rick Grimes' development plans. While waiting for everybody to arrive in order to do their usual barter, he is asked by another community leader, Ezekiel, to

Journal of French and Francophone Philosophy | Revue de la philosophie française et de langue française

Vol XXV, No 1 (2017) | http://www.jffp.org | DOI 10.5195/jffp.2017.812 
adjust the agreed upon system of exchange and "lower the price," thus introducing elements of a market system capable of adapting to what seems as changed dynamics of production. Rick is vehemently opposed and insists on maintaining the stability of a system of barter exchange and "centrally planned" prices they have developed:

Ezekiel: Supply and demand being what it is... Your price on ammunition going down now?

Rick: Supply and demand. If you know anyone else making bullets, feel free to shop around. I'm sure Dwight could start providing us with lumber.

Ezekiel: Pull the claws back, Grimes, it was just a suggestion.

Rick: Okay, okay. I guess I can't blame you for asking. It's just that we've a good system going. I don't want to screw that up."

Rick's community has an (ammunition) monopoly. But this is not the reason why he refuses Ezekiel's idea of lowering the price-even though a monopolist, he never attempts to raise prices either. Instead, he maintains a non-market system and insists on keeping the genie in the bottle. His reasons for this are interesting in the context of the above discussion: he is neither anti-technologist, nor anti-productivist. But he is anti-commercialist. He insists on maintaining the system they have for pragmatic reasons: because it works well as a system of maintaining stability, or more technically safety, in a radically dangerous world. For a narrative developing in the period where not only the memory but the direct consequences of the most recent financial crash are still active and visible, the market cannot but connote instability and danger.

Referenced constantly and explicitly, safety is the key and universal concern in Robert Kirkman's narrative. But far from simply being an overarching practical problem, "safety" becomes a type of fetish. "Keeping people safe" is the central character's mission, and variations of this phrase are repeated over and over again, often to justify decision making by group leaders. A proper polity in The Walking Dead is created only when the conditions for "institutionalizing" safety are met-good walls erected, guardsmen and patrolmen who clear the road organized and deployed. At one of the deciding moments in the narrative, the one where he realizes that "it was always people," Rick is addressing his wounded and unconscious son and emphasizing his key concerns: "safety," "security," and "hope." In the monologue he comes to the realization that a new type of stable community needs to be created. This takes a while, but after many obstacles, including war, are overcome, Rick gives a true founder's speech: "Whatever differences we had before, we must put those behind us as we move forward. The fighting is over... Now it is time for what comes next. We stand 
here united, together as one people... and it is my wish for us to remain that way...." ${ }_{46}$

Such discourse is recognizable from any national mythology. In combination with other topoi of both the US frontier myth and the ideological compulsions of the US security state of the post-9/11 period that are reproduced in the narrative, it is not surprising that many critics read it in this key, and that the narrative appears as an influential postmodern update of the US nationalist and imperialist discourse. And this is undoubtedly a correct diagnosis, but instead on being satisfied with a focus on excavation of operative ideologemes of nationalism and imperialism, I think it is important to add that this is just one of the several ways in which the narrative is incapable of extending the political imaginary with reference to which it fashions its apocalyptic-Utopian experiment. This imaginary, as it has hopefully become clear from the analysis offered here, is built up by patching fantasies of a premodern (or non-modern) community of craftsmen-guardians together with a set of ideologemes picked up from imperialist nation-building discourse (a modern formation if there ever was one). But however dubious and contradictory this might be, what is important in the context of this analysis is that the patchwork is a result of a recollective method, instinctively turning to whatever past available for a criticism of modernity it perceives as undesirable. It is predicated on a "return to," and imagines the safety it craves as lost and left behind.

This project, unsurprisingly, correlates with a political transformation of the community represented in the narrative into one that spontaneously installs a paternalistic political authority to shepherd it into safety. As Rick, with a benevolent smile of the master, tells one of the newcomers from the wild who finds herself surprised to be introduced by the rest of her group as the leader: "I was uncomfortable with the title for a long time so I know how you feel. There's no getting around it after a while. I've accepted the title and all that comes with it. I'm the leader here, yes." ${ }_{s s}$ In the next issue, exercising his rightful authority, he beats a patrolman securing the main road with a walking stick for failing to do the job: "If what we've all worked so hard and sacrificed so much to build is going to work... this road needs to be safe.... Your job is quite possibly the most important job these days. Remember that." ${ }_{49}$

A recollection of a more authentic life where we "stay with things" and practice crafts which "still [use their] tools and frames as things," where we remain "before the divinities" and at peace within the free sphere that safeguards each thing in its nature" ${ }^{{ }_{51}}$ seems also to come at the price of what Bloch calls "real democracy" and gives rise to a form of political power whose problem is not simply that it is undemocratic but much worse, that it is heroic and paternalistic.

Journal of French and Francophone Philosophy | Revue de la philosophie française et de langue française Vol XXV, No 1 (2017) | http://www.jffp.org | DOI 10.5195/jffp.2017.812 
The key question is, of course, whether that problem is a failure of imagination-an ideological limitation of this particular narrative-or a structural necessity. What I have tried to demonstrate here is that the trinity of recollective method/overcoming subjectivity/reconcretization as a critical matrix our widely resonant cultural forms instinctively turn to for criticisms of (capitalist) modernity, entails a wholesale abandonment of modernity's premises. The ideological effect of this is quite problematic, as for this particular critical matrix, the return to the fold of "auratic authority" is, indeed, a structural consequence. Perhaps not in a direct causal way, but insofar as it begins with an imaginary return, pseudo-gnostically perceives and discards the structural compulsions of modern subjectivity as corrupt, and collapses the essential reality of historical order into ontology, its critical criteria (and implied positive projections) will both be unable of escaping the siren call of maintaining ontological consistency at the price of ontic apocalypse, as well as incapable of recognizing the redeeming aspects of modernity. In a wider context of the triumph of capitalist universality, this is also a symptom of a lack of a widely available alternative critical matrix. Alternative not simply in the sense of "some other," but in the sense of a criticism of capitalist modernity from a more dialectical perspective of alternative modernity (the only historically existing form of which thus far was and is communism). If we try to envision such an alternative along the lines of the trinity, it would replace the recollective method with a speculative one, perhaps closer to Collier's decisionism than Blochian futureoriented messianism, the insistence on overcoming subjectivity with a better theorization of the subject (Žižek's analysis of Heidegger's political choices referenced above provides a good start), and reconcretization will most likely be a secondary consequence of the necessary replacement of an exchange-value-driven modern order with an alternative one better suitable for "true dwelling." In such an order, perhaps, instead of inviting the antimodern apocalypse to discover the poetic awaiting us there, we might decide to remain within history and work with the salvage of prose we find here, towards a future where the apocalypse might seem as out of place as Utopia is today..$^{22}$

1 Martin Heidegger, “Building Dwelling Thinking," in Poetry, Language, Thought, trans. AlbertHofstadter (New York: Harper Perennial Modern Classics, 2001), 151.

2 Julian Young, Heidegger's Later Philosophy (Cambridge: Cambridge University Press, 2002), 51.

${ }^{3}$ On the question of whether a "political dimension" and a "contribution to the current political situation" can be extracted from Heidegger's work and how, see both Slavoj Žižek's "Why Heidegger Made the Right Choice in 1933" and Miguel de Beistegui's reply to that essay "Another Step, Another Direction."

Journal of French and Francophone Philosophy | Revue de la philosophie française et de langue française Vol XXV, No 1 (2017) | http://www.jffp.org | DOI 10.5195/jffp.2017.812 
${ }^{4}$ Heidegger, "Building Dwelling Thinking," 154.

${ }^{5}$ Ibid., 147.

${ }^{6}$ Fred Dallmayr, "The Discourse of Modernity: Hegel, Nietzsche, Heidegger, and Habermas," in Habermas and the Unfinished Project of Modernity, ed. Maurizio Passerin d'Entrèves and Seyla Benhabib (Cambridge: The MIT Press, 1997), 82.

${ }^{7}$ Ernst Bloch, The Principle of Hope, Vol I-III (Cambridge: The MIT Press, 1996), 1375-1376.

${ }^{8}$ Anson Rabinbach, In the Shadow of Catastrophe: German Intellectuals between Apocalypse and Enlightenment (Berkeley: University of California Press, 1997) 97.

${ }^{9}$ Heidegger, "Building Dwelling Thinking," 159.

${ }^{10}$ Ibid.

${ }^{11}$ Ibid., 147.

${ }^{12}$ Ibid., 149.

${ }^{13}$ Ibid., 154

${ }^{14}$ As "real sparing" is positive and it happens when "we leave something in its own nature," it can be concluded that this nature, or order as we name it here, insofar as it manifests as "returned specifically to its being," is also by extension positive. Ibid., 147.

${ }^{15}$ This might be the place to mention that this particular problem was the basis for Habermas criticism of the later Heidegger as advocating a "diffuse readiness to obedience towards an auratic, but indefinite authority." Dallmayr, "The Discourse of Modernity," 79. For an overview of Habermas' argument against Heidegger as well as a criticism of that argument see Dallmayr.

${ }^{16}$ Young, Heidegger's Later Philosophy, 99.

${ }^{18}$ Brian M. Stableford, "End of the World," in The Encyclopedia of Science Fiction, eds. John Clute, David Langford, Peter Nicholls, and Graham Sleight. Gollancz, April 9, 2015. http://www.sfencyclopedia.com/entry/end_of_the_world.

${ }^{19}$ Frank Kermode, The Sense of an Ending: Studies in the Theory of Fiction (New York: Oxford University Press, 2000), 97.

20 "Genericity concerns...the placement of a text in relation to open generic categories.... The genericity is a socio-cognitive necessity that relates each text to the inter-discourse of a social formation." (Adam and Heidmann, as quoted in Zipes 24).

21 Jacques Derrida, "Of An Apocalyptic Tone Recently Adopted in Philosophy," Oxford Literary Review 6, no.2 (1984), 22.

${ }^{22}$ We can illustrate this by thinking of films such as A. González Iñárritu's Babel (2006), or Oliver Stone's Wall Street: Money Never Sleeps (2010). For both, overcomplexity is a key representational problem. The first one represents it structurally, by way of a narrative dramatization of a chain of events that spans several continents and points in time. The second is less subtle and simply plants recognizable contemporary symbols of business arcana (graphs, skyscrapers, grids) into the narrative, suggesting the incomprehensibility of capital. A good example of an antidote to that type of approach, abandoning "overcomplexity" as a kind of ideological smoke screen and providing a dramatization of capital-in-operation in a classical Aristotelian fashion, is J.C. Chandor's Margin Call (2011).

Journal of French and Francophone Philosophy | Revue de la philosophie française et de langue française Vol XXV, No 1 (2017) | http://www.jffp.org | DOI 10.5195/jffp.2017.812 
${ }^{23}$ As Gilens and Page state in the abstract of their widely-circulated study in which they tried to empirically prove precisely this point: "The results provide substantial support for theories of Economic-Elite Domination and for theories of Biased Pluralism, but not for theories of Majoritarian Electoral Democracy or Majoritarian Pluralism." See Gilens and Page.

${ }^{24}$ Fredric Jameson, Postmodernism; or, The Cultural Logic of Late Capitalism (Durham: Duke University Press), 21.

${ }^{25}$ Heidegger, “Building Dwelling Thinking," 149.

${ }^{26}$ Young, Heidegger's Later Philosophy, 99.

${ }^{27}$ Deleuze, Gilles and Felix Guattari, Anti-Oedipus, trans. Robert Hurley, Mark Seem, \& Helen R. Lane (London: Continuum, 2003), 368.

${ }^{28}$ Deleuze, Gilles and Felix Guattari, A Thousand Plateaus: Capitalism and Schizophrenia, trans. Brian Massumi (London: Continuum, 2004), 470.

${ }^{29}$ See McNally, Harman, Cvek.

${ }^{30}$ Comaroff, Jean and John Comaroff, “Alien Nation: Zombies, Immigrants and Millenial Capitalism," South Atlantic Quarterly 101, no.4 (2002): 779-805.

${ }^{31}$ Steve Shaviro, “Capitalist Monsters," Historical Materialism 10, no.4 (2002): 281-284.

${ }^{32}$ Peter Paik, "The Gnostic Zombie and the State of Nature: On Robert Kirkman's The Walking Dead," Social Science Research Network, August 18, 2011: 8.

${ }^{33}$ Robert Kirkman, “Days Gone By Part I," The Walking Dead \#1 (October 2003).

${ }^{34}$ Robert Kirkman, “No Way Out Part V,” The Walking Dead \#84 (April 2011).

${ }^{35}$ Robert Kirkman, “Life and Death Part I," The Walking Dead \#139 (March 2015).

${ }^{36}$ Robert Kirkman, “A New Beginning Part I,” The Walking Dead \#127 (May 2014).

${ }^{37}$ Kirkman, "Life and Death Part I."

${ }^{38}$ Heidegger, "Building Dwelling Thinking," 158.

${ }^{39}$ Robert Kirkman, “Compendium One," The Walking Dead (2009).

${ }^{40}$ Robert Kirkman, “A New Beginning Part V,” The Walking Dead \#131 (September 2014).

${ }^{41}$ Robert Kirkman, “Life and Death Part VI,” The Walking Dead \#144 (July 2015).

${ }^{42}$ Andrew Collier, In Defense of Objectivity and Other Essays: On realism, existentialism, and politics (London: Routledge, 2004), 75.

${ }^{43}$ Ibid., 77.

${ }^{44}$ Kirkman, "Life and Death Part I," The Walking Dead \#139.

${ }^{45}$ Interestingly, even in the original proposal for the comic sent to publishers in late 2002, in the immediate post-9/11 period, Kirkman/Moore wrote the following: "This book is about a man who will do anything to ensure that his family is safe." The proposal can be found in the 10th anniversary edition of the issue.

${ }^{46}$ Robert Kirkman, “All Out War Part II,” The Walking Dead \#126 (April 2014). 
${ }^{47}$ For an elaboration of sources and reading of intertextual references, as well as an interpretation of the function of violence in the narrative in this context see Pokornowski and Young, P. Ivan.

${ }^{48}$ Robert Kirkman, “A New Beginning Part II,” The Walking Dead \#128 (June 2014).

${ }^{49}$ Robert Kirkman, “A New Beginning Part III,” The Walking Dead \#129 (July 2014).

${ }^{50}$ Heidegger, “Building Dwelling Thinking," 158.

${ }^{51}$ Ibid., 147.

${ }^{52}$ The writing of this article was supported in part by the Croatian Science Foundation (CSF/HRZZ).

Journal of French and Francophone Philosophy | Revue de la philosophie française et de langue française Vol XXV, No 1 (2017) | http://www.jffp.org | DOI 10.5195/jffp.2017.812 